News, Notes and Queries

If this was the only instance of gangrenous ergotism due to damaged grain that has been recorded in England, then the person who wrote the inscription in Wattisham Church used a particularly apt expression when he called it 'A singular calamity'.

ACKNOWLEDGEMENTS

My thanks are due to W. R. Sergeant, Archivist of the East Suffolk Record Office, to the Librarian of the Wellcome Institute of the History of Medicine and my secretary, Mrs. M. O. Bear.

\title{
REFERENCES
}

BARGer, G., Ergot and Ergotism, London, Gurney \& Jackson, 1931.

Diocesan House, Ipswich. Personal Communication concerning churches dedicated to St. Anthony.

Garrison, F. H., An Introduction to the History of Medicine, Philadelphia, W. B. Saunders, 1929.

Haggard, H. W., Devils, Drugs and Doctors, London, Heinemann, 1957.

Ipswich Journal, 17 April, 1 May, 8 May, 22 May 1762.

Munk, W., Roll of the Royal College of Physicians of London, London, 1878.

Parish Register, Wattisham, 1761-1800. East Suffolk Records Office, Ipswich.

Phil. Trans. R. Soc. Lond., 1762, 87, extract of a letter from Charlton Wollaston, M.D., F.R.S. to William Heberden, M.D., F.R.S., dated Bury St. Edmunds 13/Apr/1762 relating to a case of mortification of limbs in a family at Wattisham in Suffolk (read 22 April 1762). 84, 1762 extract of a letter from Rev. James Bones, M.A. Minister of Wattisham near Stowmarket in Suffolk to George Baker, M.D., F.R.S., relating to the case of mortification of limbs in a family there (read 6 May 1762). 85, 1762, extract of a second letter from Rev. Mr. Bones to Dr. Baker (read 6 May 1762).

DAVID VAN ZWANENBERG

\section{THE SOCIETY FOR THE SOCIAL HISTORY OF MEDICINE}

The following meetings are announced:

16 June 1973: One-day meeting at Birmingham on 'Child Health'.

11-13 July 1973: International meeting at Düsseldorf, West Germany. A comparative study of British and German developments in health and welfare, occupational health, mental health, military medicine, medical institutions and education, and medical care.

Particulars of these meetings and membership of the Society are available from the Society's Secretary, Mr. G. Wilson, 183 Euston Road, London NW1 2BP.

\section{INTERNATIONAL CONGRESS ON THE HISTORY OF PHARMACY}

The next International Congress on the History of Pharmacy will be held in Paris from 24 to 29 September 1973. Full information and registration forms may be obtained from the Secretary, 75 rue Ordener, Paris 75018, France. 